\title{
Film as cultural diplomacy: South Korea's nation branding through Parasite (2019)
}

\author{
Seow Ting Lee ${ }^{1}$
}

Revised: 29 June 2020 / Accepted: 29 October 2020 / Published online: 6 January 2021

๑) Springer Nature Limited 2021

\begin{abstract}
This study examines the nation branding of South Korea through the Oscar-winning film Parasite (2019) to understand the South Korean government's approach toward cultural diplomacy, and its outcomes. Despite growing depoliticalization and decentralization, South Korea's cultural diplomacy policy remains unilateral in embracing Parasite's success for nation branding while drawing on expanding private-sector resources to produce and market the film. To explicate South Korea's nation brand vis-à-vis Parasite, a Leximancer analysis of 8808 texts investigated concepts that are associated with the film as a complex bundle of images, meanings, associations, and experiences in the minds of international audiences. The texts associate Parasite with the national entity of South Korea and the country's most significant cultural content export, the Korean Wave. Sentiment analyses through Leximancer also show positive attitudes, thus helping to reinforce the nation branding of Parasite and its successes as a tangible South Korean national resource, consistent with a soft power approach.
\end{abstract}

Keywords Cultural diplomacy $\cdot$ Culture $\cdot$ Nation branding $\cdot$ Public diplomacy $\cdot$ Parasite $\cdot$ Film $\cdot$ South Korea $\cdot$ Korean Wave

\section{Introduction}

On February 10, 2020, Parasite (2019) from South Korea became the first non-English speaking film to win Best Picture at the Academy Awards, marking a major cultural industry breakthrough for the East Asian country. The film's success reflects not only a significant global expansion of the country's nascent cultural industries but also a strategic nation branding opportunity for enhancing South Korea's soft power and cultural diplomacy.

Director Bong Joon-ho's social satire about the uneasy, symbiotic (or parasitic) relationship between a poor family, the Kims and the wealthy Parks, is universally relatable. The film, with Korean as its primary language, was set in South Korea, filmed in Seoul alleyways and a studio set in the city of Goyang, and was produced by an almost exclusively Korean cast and crew who gave international media interviews and Oscar acceptance speeches in Korean

Seow Ting Lee

seowting.lee@colorado.edu

1 Department of Advertising, Public Relations, and Media Design, University of Colorado at Boulder, 1511 University Avenue, UCB 478, Boulder, CO 80309, USA using interpreters. As a "foreign" film to audiences outside South Korea, Parasite resonated with foreign viewers due to "its ability to convey the same message to international audiences without relying on cultural references to make it relevant and understandable" (Vandenburg 2019).

In the opening scene, Wi-Fi serves as a metaphor for division as well as coexistence. In a dingy Seoul semi-basement apartment, a young man named Kim Ki-woo crouches near a window searching for an elusive Wi-Fi signal. Ki-woo and his struggling family - who fold pizza boxes for a livingleech off their neighbors' Wi-Fi connections. In that scene, the neighbors have turned off theirs, prompting a panic among the Kims who cannot function without connecting to the Internet for social networking and for ordering pizza for lunch - universal references that are likely to be far from foreign to many audiences around the world.

Parasite first premiered at the 2019 Cannes Film Festival on May 21, 2019 to become the first South Korean film to win the Palme d'Or. The film also chalked up successes at the Golden Globe Awards (Best Motion Picture, Best Director, and Best Screenplay), the BAFTA (Best Foreign Language Film, Best Original Screenplay, Best Film, and Best Direction), and the Screen Actors Guild Awards (Best Cast in a Motion Picture). Seven months after Cannes, 
Parasite also made history in the 92 years of the Academy Awards for being the first film not in the English language to win Best Picture. It also won Oscars for Best Director, Best Foreign Language Film, and Best Original Screenplay. The film, funded by Seoul-based Barunson Entertainment \& Arts Corporation, edged out Hollywood competitors made for nine times as much (Kim and Lee 2020, 2020). Grossing over \$267 million worldwide on a modest production budget of $\$ 11$ million, it is not only a critical accomplishment but also a commercial success. When Parasite first opened in North America at the end of October 2019-despite the Palme d'Or, only three screens showed the film due to a lack of interest in subtitled films. Parasite's Oscar wins subsequently generated much publicity and interest, leading to thousands of screenings (Economic effects 2020).

Parasite's global success is a new crest in the Korean Wave (or Hallyu in Korean), a broad theme describing South Korea's cultural economy and the rapid diffusion and export of its popular culture products to global cultural markets, from digital contents such as video/computer games, webtoons, K-pop and television dramas to food, fashion, and language (Hangul). With the influx and commanding popularity of these products across the globe, the government has leveraged the Korean Wave as both a domestic and foreign policy tool to strengthen its economic diversification, export profile, and cultural and public diplomacy outcomes (Jang and Paik 2012; Jin 2020; Kang 2015; Kim 2017, 2018; Kim and Jin 2016; Lee 2009; Nye and Kim 2013). With a population of 51 million people, South Korea today has emerged as a cultural powerhouse shaping the zeitgeist of global culture; it has become to many a playbook of stateled cultivation of soft power, what Nye (2008) described as "the ability to affect others to obtain the outcomes one wants through attraction rather than coercion or payment" (p. 94). According to Nye, "The resources that produce soft power arise...from the values... a country expresses in its culture, in the examples it sets by its internal practices and policies, and in the way it handles its relations with others. Public diplomacy is an instrument that governments use to mobilize these resources to communicate with and attract the publics of other countries" (p. 94).

Within the context of the changing role of the nationstate, South Korea's nation branding through Parasite helps us to understand the South Korean government's approach toward cultural diplomacy. Like in many countries, the role of government is fundamental to the growth of cultural industries. In South Korea, the government has developed a distinct cultural policy based on state-developmentalism, public diplomacy, and nation branding (Kim and Jin 2016; Jin 2020) to meet its foreign policy agendas that are not without tensions. South Korea, like other middle powers, face difficulties in terms of visibility on the global stage and recognition from others. Global publics are either unaware of them, or hold negative opinions of them, thus compelling middle powers to seek out global attention through less conventional means. In the Soft Power 30 Index (SP30), South Korea placed 19th in 2020-its best showing since the index was launched in 2015. Across all categories of SP30, the country's lowest ranking is in its combined polling score, suggesting that there is a gap between its soft power assets and perceptions of the outside world (Soft Power 30 Index 2019).

Although studies have addressed the Korean Wave and public diplomacy, they viewed the Korean Wave as a single mass of cultural products without differentiation (Ang et al. 2015; Elfving-Hwang 2013; Jang and Paik 2012; Jin 2016; Kim 2018; Kim 2020a; Kim and Jin 2016; Lee 2009; Lee 2013; Lovric 2018; Nye and Kim 2013). This study, in focusing on a single Korean Wave cultural product-the film Parasite - takes into consideration the importance the context in which the product functions to provide a more in-depth understanding of public diplomacy and nation branding processes at work. So far, no published research has examined the film Parasite within a converged contextual framework of public diplomacy, cultural diplomacy, and nation branding.

\section{Nation brand as images, meanings, and associations}

Nation branding refers to the use of branding and marketing communications strategies to promote a nation's image (Dinnie 2008; Fan 2006; Gudjonsson 2005; Szondi 2008). It is "a process by which a nation's images can be created or altered, monitored, evaluated and proactively managed in order to enhance the country's reputation among a target international audience" (Fan 2010, p. 101).

A nation brand is inherently a complex, multifaceted construct. It is about how a country is seen by others, and comprises "a complex bundle of images, meanings, associations and experiences in the minds of people" (Fan 2010, p. 98). As a "mental image of the country held by foreign people," a nation brand is "the total sum of all perceptions of a nation in the minds of international stakeholders, which may contain some of the following elements: people, place, culture/ language, history, food, fashion, famous faces (celebrities), global brands and so on" (Fan 2010, p. 98). Every nation has a "brand," with or without any efforts in nation branding, because "each country has a certain image to its international audience, be it strong or weak, current or outdated, clear or vague" (Fan 2006, p. 12).

Anholt (2007) viewed nation branding as a metaphor for how effectively countries compete with each other for favorable perception-be it in exports, governance, tourism, investment and immigration, culture and heritage, or 
people. Nation branding is seen as a powerful political tool, especially among small, peripheral nations or middle powers eager to strengthen their positions and to compete against the clout of superpowers (Volcic and Andrejevic 2011). In particular, tourism promotion has dominated the nation branding activities of small and middle power nations (e.g., Avraham 2018; Fan 2006; Scott et al. 2011).

Nation branding is related to the concept of public diplomacy. Traditionally, public diplomacy refers to "government communication aimed at foreign audiences to achieve changes in the 'hearts or minds' of the people" (Szondi, p. 6). Early definitions of public diplomacy also evolved around strategies of promotion and persuasion and were closely related to self-interest and reputation or impression management-similar to image promotion in nation branding. As noted by Szondi (2008), the two concepts-nation branding and public diplomacy-are related and show a significant degree of integration.

On the other hand, cultural diplomacy is a form of public diplomacy, and refers to a nation-state's strategic endeavors to promote its national interest "through making its cultural resources and achievements known overseas and/or facilitating cultural transmissions abroad" (Cull 2008, p. 31). According to Mark (2009), cultural diplomacy is "a subset of public diplomacy or the operation of a state's culture in support of its foreign policy goals, to combat stereotyping, develop mutual understanding, and advance national reputation and relationships across the border" (p. 9).

The instrumental application of culture by governmental actors for the advancement of national interests underpins cultural diplomacy, but over the years, the conceptual field of the term cultural diplomacy has broadened to encompass "the exchange of ideas, information, art and other aspects of culture among nations and their peoples to foster mutual understanding" (Cummings 2003, p. 1).

Nation branding is concerned with a country's whole image on the international stage; it covers not only political and economic dimensions but also the cultural (Anholt 2007; Fan 2006; Quelch and Jocz 2004). The relationship between nation branding and cultural diplomacy is made explicit by Dinnie's definition of a nation brand as "the unique, multidimensional blend of elements that provide the nation with culturally grounded differentiation and relevance for all of its target audiences" (p. 15). This definition not only targets audiences in the minds of whom nation brands are situated but also, as pointed out by Szondi (2008), makes an important reference to a nation's culture and cultural products to allow for a conceptual integration of the concepts of nation branding, cultural diplomacy, and public diplomacy.

An important conceptual direction for cultural diplomacy converges on the situating of culture and the exchange of ideas within a country's resource, consistent with Nye's postulation of soft power in public diplomacy as an outcome or "getting others to want the outcomes that you want" (2004, p. 5). Threats, according to Nye (2004), are "also useful to influence people to act in ways that align with one's desires," but "soft power, rather, is attractive power, inducing an active change in people's preferences that in turn change their actions" (p. 6). Similar to soft power, nation branding emphasizes the construction and dissemination of a national image abroad for the purposes of directing the attitudes and behaviors of foreign audiences. For instance, Nye (2009) viewed the cultural phenomenon of the Korean Wave as an example of soft power public diplomacy that has heightened South Korea's global visibility and clout.

In the context of middle power South Korea's cultural diplomacy endeavors, Nye and Kim (2013) pointed out that the country's global expansion of its popular culture in the twenty-first century signifies the Korean Wave's potentiality as a set of soft power resources that may have a significant and complex impact on cultural diplomacy as well as on the country's trade, tourism, the academy, and other national interests across multiple contexts. According to Nye and Kim (2013), the soft power of any country rests primarily on three resources: the attractiveness of its culture; its political values, when it lives up to them at home and abroad; and its foreign policies, when they are seen as legitimate and having moral authority (p. 32). In particular, Nye and Kim (2013) suggested that "Korea needs to pay more attention to soft power" (pp. 31-32) as one of the country's most significant cultural diplomacy strategies, as others, in particular the U.S. government, have used the film industry successfully as a resource for cultural diplomacy.

\section{Cultural diplomacy through film}

Film is one of the most powerful mediums of cultural diplomacy. With its wide reach and accessibility, film has a long history of not only entertaining but also educating, breaking stereotypes, and transcending borders at different levels to foster mutual understanding through exchange of ideas, information, art, and other aspects of culture among nations and their peoples. A number of successful films include Jean Renoir's anti-war classic La Grande Illusion (1937), Stanley Kubrick's political satire Dr. Strangelove (1964), and JeanJacques Annaud's Seven Years in Tibet (1997) that tells the story of an Austrian mountain climber who becomes friends with the Dalai Lama. The film, which highlighted Tibet's plight to international audiences, did not sit well with the Chinese government who considers Tibet part of its sovereign territory. Through the Lord of the Rings trilogy, New Zealand's stunning landscapes captivated movie fans all over the world and helped the country reap a $50 \%$ increase in tourist arrivals in the country since the 2001 release of the first film in the trilogy. 
Few democratic countries, however, have utilized their home-grown films for nation branding due to the complex and unpredictable associations that overseas audiences could cultivate depending on the content of a particular film and how it could be interpreted. For non-English-speaking films attempting to break into global cultural markets, the language barrier could pose a challenge. More importantly, too deliberate and explicit a government-led attempt at nation branding using its country's film could evoke unsavory perceptions of propaganda, while too distant a national connection could weaken the nation branding potential.

Lovric (2018) examined the soft power potential of international film exports and film industries as tools of cultural diplomacy by South Korea, Japan, and China. Compared to Japanese and Chinese film stories that often take place in a distant past or center around relatively safe topics, South Korean films deal with contemporary society and display a much higher level of stylistic boldness, and "challenge audiences through genre-bending practices and by asserting the importance of the image within a cinematic and cultural context" (p. 613).

Two research questions guide this study. The first addresses the construction of Parasite as a cultural diplomacy tool: why and how did South Korea position the film for nation branding and cultural diplomacy? The second research question addresses outcomes of the film: to what extent has the film contributed to the nation branding of South Korea?

\section{Method}

To examine both the process and outcome of Parasite as a tool for cultural diplomacy and nation branding, we utilized a case study (Yin 1984, 2002, 2014). Case studies are in-depth investigations of a single individual, group, event, or community, and are particularly suited for answering why and how questions in situations "when the boundaries between a phenomenon and context are not clear and the researcher has little control over the phenomenon and context" (Yin 2002, p. 13). Yin (2014) described case study research as "an empirical inquiry that investigates a contemporary phenomenon (the 'case') in depth and within its realworld context" (p. 16). Over the last 40 years, case studies have evolved into a "pragmatic, flexible research approach, capable of providing comprehensive in-depth understanding of a diverse range of issues across a number of disciplines" (Harrison et al. 2017).

Primarily exploratory and explanatory, case studies seek to understand an issue in real-life settings via triangulation of sources and methods for a comprehensive perspective of the issue studied. Using a triangulated approach, this study incorporates multiple sources of evidence including government communication, news media coverage, media interviews, and sentiment analyses to explicate international perceptions of South Korea in relation to Parasite.

\section{Riding on the Korean wave}

The construction of Parasite as a cultural diplomacy tool can be explicated within the context of South Korea's cultural industry development. In media interviews, Parasite director Bong asserted that the Oscar Best Picture win would not have been possible without the long-running success of the Korean Wave over the past 20 years or more (Son 2020). For decades, dictatorial governments in South Korea suppressed artistic creativity, but post-democratization, a cultural renaissance dating to the late 1990s' inception of the Korean Wave re-energized the film industry. State censorship stymied the development of South Korean cinema until 1996, when the Constitutional Court ruled that state-led film censorship was unconstitutional. Bong's positioning of Parasite as a product of the Korean Wave is understandable. Since the late 1990s, the Korean Wave has been a targeted cultural diplomacy tool for the government to spread Korean culture worldwide. Since the early 2000s, Bong-who made his directorial debut in the dark comedy Barking Dogs Never Bite (2000)_has joined other South Korean directors like Park Chan-wook (Oldboy, 2003; Thirst, 2009), Kim Ki-duk (The Isle, 2000), and Kim Jee-woon (A Tale of Two Sisters, 2003), and Lee Chang-dong (Oasis, 2002) to form a coterie of New Korean cinema shaping the international festival circuit.

Nye and Kim (2013) attributed the rise of the Korean Wave to the government's decision to play a driving force behind the phenomenon after recognizing its potential for effective cultural diplomacy. The Korean Wave provided "a meaningful opportunity for the government to take advantage of newly emerging cultural and public diplomacy to promote Korean cultural advantages in a globalizing world" (Jang and Paik 2012, p. 201). The cultural phenomenon contributed to South Korea's soft power "by providing opportunities for the manipulation of Korea's images, extending a network effect of Korean popular culture, and also producing internationally influential heroes and celebrities" (Lee 2009, p. 123), enabling the government "to enhance its national image and acquire soft power for the attractiveness of its cultural content" (Jin 2020).

As an export, South Korean popular culture has expanded beyond entertainment or art to become a means by which the country can "promote human development, nurture intercommunity interaction, and establish collaboration between countries," leading Jin (2020) to argue that the government is utilizing the Korean Wave "in support of its foreign policy goals.” Jin (2020) highlighted an episode from 2012, 
when South Korean actor Jeon Kwang-ryul, the lead in the K-drama Huh Jun that was wildly popular in Iraq, visited the country on the invitation from the then-First Lady, Hero Ibrahim Ahmed. She also invited the Korean Embassy in Iraq and South Korea's Ministry of Foreign Affairs and Trade to issue a special passport permit for South Koreans in the tourism-prohibited region (Kang 2012).

\section{Governmental efforts}

In 2009, South Korea became the first country to establish a presidential council to coordinate efforts to improve its national image and national brand. Under then-President Lee Myung-bak, the government placed complex diplomacy and value diplomacy as the main policy objectives to improve cultural and public diplomacy along with enhancing national image and national brand (Jang and Paik 2012). The presidential council served as a general control tower on the country's nation branding activities, including coordinating efforts with the Ministry of Foreign Affairs and Trade, which in 2010 published its first Cultural Diplomacy Manual. In the manual, then-Foreign Affairs Minister Yoo Myung-hwan stated that "along with diplomatic efforts focused on national defense in the 1980s and the economy and trade in the 1990s, culture will be the third pillar of diplomatic power in the twenty-first century" (Ministry of Foreign Affairs 2010). In August 2011, the presidential council hosted a three-day "Korea Nation Branding Convention 2011" under the slogan of "Hallyu, into the Future with the World." Although the tenure of the council was shortlived, as it was disbanded in 2013 after a change of government, it played a significant role in the branding of Korean pop entertainment culture overseas between 2009 and 2013 that served as a foundation for future successes (Kim 2017).

Besides the Ministry of Foreign Affairs and Trade, the Ministry of Culture, Sports, and Tourism (KMCST) has also been instrumental in accomplishing the government's foreign policy objectives through the Korean Wave (Yoo 2018). The KMCST is a central agency whose main goals are to promote tourism as a national strategic industry, accelerate the growth of the sports industry, and improve Korea's reputation as a global cultural power (Ministry of Culture 2018). Among its responsibilities are organizing conferences, disseminating government communication to promote Korean Wave artistes and productions, networking with other countries to facilitate investment in Korean popular cultural products and exports (Yoo 2018). In 1984, the South Korean government through the Korean Film Council (a unit of the Ministry of Culture, Sports and Tourism) established and funded the Korean Academy of Film Arts (KAFA) to nurture the country's film arts talents. Parasite director Bong graduated from a two-year program at KAFA, which has so far trained more than 700 film directors, animators, and cinematographers. Bong's 1994 KAFA graduation film, Incoherence, was a cult success that helped paved the way to his early hits such as Memories of Murder (2003) and The Host (2006).

\section{A boost from technology}

Aside from the tremendous governmental support, the proliferation of digital platforms has made the Korean Wave a global phenomenon. Until the late 2000s, the popularity of the Korean Wave was limited to within Asia with fans mostly in their teens and twenties. However, since the early 2010s, social media platforms such as YouTube, Facebook, and Viki have played a primary role in disseminating South Korean cultural content more widely in global cultural markets (Jin 2020; Kim 2020a). On December 21, 2012, South Korean artiste Psy's music video for Gangnam Style featuring the horse dance exceeded one billion views on YouTube. It was the first video to do so in the history of the social networking platform's history. The past decade has witnessed an even more rapid ascent in South Korea's status as an entertainment cultural force, as seen in the rise of South Korean boy band BTS. The band released its new album Map of the Soul: 7 on February 21, 2020-days after Parasite was crowned best film at the Academy Awards. Map of the Soul: 7 was the seven-member South Korean boy band's fourth No. 1 album on the Billboard 200.

In 2019, CJ E\&M, South Korea's largest entertainment company and a key financial backer of Parasite, entered into a strategic partnership with Netflix based on a multi-year content production and distribution agreement. Through social media and on-demand platforms like YouTube and Netflix, digital formats are driving a transnational cultural consumption of Korean contents, as exemplified by Parasite, BTS, Psy, and popular made-for-Netflix K-dramas such as Kingdom, Itaewon Class, and Crash Landing on You.

\section{Private-sector support}

The persistent efforts of South Korean entertainment companies and investors also are paying off. The South Korean government has a unilateral policy to promote the Korean Wave but it has increasingly drawn on expanding privatesector resources, as it seeks to decentralize its cultural diplomacy efforts. This is evident in the case of Parasite, which is a wholly private-sector initiative. Credit for the success of Parasite must also go to the film's executive producer, South Korean businessswoman Miky Lee, a Samsung heiress and one of the early investors in DreamWorks. Lee established an entertainment and media subsidiary CJ E\&M within her family's CJ Group's conglomerate. Growing up, the 62-yearold Lee was struck by the lack of global exposure to Korean content, especially in the U.S. where she was born and has 
lived for long periods. Lee's approach, in her own words, was to "push our Korean content to other people to watch it, keep just pushing it, pushing it" (Hollingsworth 2020).

Lee is also a vice-chairman of CJ Group, which started out as a food company and is South Korea's largest purveyor of TV programs and movies as well as home-shopping services. Lee's CJ Group, through its subsidiary CJ E\&M, not only finances and distributes films but also owns a stable of record labels and talent-management agencies, making it an important player in the Korean Wave. CJ Group distributed Parasite in South Korea, but for its release in the U.S. and Canada, Lee worked with U.S. agency Neon, tapping on her extensive global connections especially in the U.S. Neon CEO Tom Quinn, who has been involved in distributing several of Parasite director Bong's earlier films including The Host (2006) and Snowpiercer (2013), is a veteran of independent cinema, with past roles at Magnolia Pictures and Weinstein Co. Neon launched an extensive marketing campaign for Parasite that included social marketing content such as enticing grid takeover on Instagram and sharp video ads with interlocking storylines.

After Parasite's Oscar achievements, stocks of the companies behind Parasite soared in value. The shares of Barunson, which invested USD11 million in the film, hit record highs; after closing at 2000 won (USD1.70) on Feb 7, its shares more than doubled to 4470 won on February 10. CJ Group also saw its shares jump more than $10 \%$ the day after the Oscars.

For decades, within a framework of state-led cultural policy, public-private collaboration has been an established model of development. This model has persisted, albeit with some shifts over the past two decades, in the making of Parasite. Since the 1960s, South Korea has pursued stateled developmental models and a top-down and export-led economy (Kim and Jin 2016). Although the government has adopted neoliberal reforms since the early 1980s-which reduced its intervention in many parts of society-it has not entirely given up its crucial role and has continued to develop its state-led cultural policy, as seen in the national economy, to which cultural industries are situated prominently (Kim and Jin 2016; Heo 2015; Jin 2016).

Apart from working closely with private entities and supporting the culture industries through the activities of its ministries of Ministry of Foreign Affairs and Trade, the Ministry of Culture, Sports, and Tourism (KMCST), and the Presidential Council on Nation Branding, the government invests in cultural productions through grants. In 2020, the Korean Film Council allocated 100 billion won (USD85 million) for film development, a $32 \%$ increase on last year's (Bicker 2020). Parasite, however, was not a recipient of such government grants. Given the profile of its director and the film's commercial potential paved by the popularity of the Korean Wave, it was natural for Parasite to be a wholly private-sector project funded by commercial interests, consistent with the government's decentralized approach of tapping on expanding private-sector resources to produce and market South Korean cultural contents for export.

\section{Domestic economic imperatives}

The expansion of South Korea's cultural industries has boosted its domestic economy (Jin 2020; Xu and Hahm 2018). Export of cultural goods and services has grown exponentially; between 1998 and 2019, it chalked up a fortytime increase from $\$ 188.9$ million to $\$ 12.3$ billion in 2019 . According to the Korean Foundation for International Cultural Exchange's (KOFICE) Hallyu Impact Research Report 2020, Korean Wave exports rose $22.4 \%$ in 2019 from the previous year. The report, which analyzed the popularity of Korean cultural products, also produced a Hallyu Index based on a survey of 7800 people in 16 countries and South Korean export reports from 14 domestic industries. By measuring the impact of Korean Wave cultural exports on the domestic economy, it found that art and cultural content exports in 2017 were worth USD 3.8 billion, $18.7 \%$ higher than such exports in 2016 . The largest single export category was video/computer games, worth some USD \$2.3 billion, and the highest year-on-year increase was seen in broadcasting (57.1\%) and music (21.2\%) (Xu and Hahm 2018).

The popularity of South Korean cultural content exports has also prompted South Korean corporations to employ more cultural content creators including writers, film directors, television producers, music composers, and crew members. According to the Korea Creative Content Agency's 2018 White Paper, the number of employees in South Korean cultural industries rose from 575,060 in 2005 to 644,847 in 2017 . This number represents $3 \%$ of the entire South Korean job market, and is bigger than that of the semiconductor, computer, and telecommunications sectors in 2017 (Contents Industry White Paper 2018).

The global success of the Korean Wave has also generated a ripple effect to benefit other industries including tourism, cosmetics, foods, fashion, and electronics (Jin 2020). Every USD100 worth of export of Korean Wave cultural content generated an attendant export of USD248 worth of consumer goods from South Korea between 2011 and 2016 (Korean Development Institute, n.d.). In particular, K-pop cultural content exports generated as much as 17.7 times increase in exports of consumer goods including cosmetics, food, and fashion (Korean Development Institute, n.d.). In 2019, for instance, K-pop exports brought in \$533 million, surpassed by tour products ( $\$ 2.65$ billion) and cosmetics (\$969 million). Jin (2020) observed that there is a common saying among South Koreans that digital contents and popular culture "feed the nation" that reflects how important 
the influence of the Korean Wave is on the South Korea's domestic economy.

Parasite, like its other successful Korean Wave counterparts, has spawned a range of cultural and commercial ripple effects through spin-offs that are uniquely South Korean. With many fans of the movie copying jokes, gestures, food, and recipes that appear in the film, some market analysts have forecasted that the overall Asian food market will gain popularity around the world thanks to Parasite (Kim 2020b). The attention paid to Parasite by opinion leaders such as celebrities and influential bloggers, and the global public helped to raise the film's cultural prominence and influence.

A Parasite-inspired noodle dish called jjappaguri (translated as "ram-don" in the film's English subtitles)—a combination of black bean sauce-based instant noodle brand Jjapaghetti and instant spicy udon ramen brand Neoguri-went viral and boosted sales for the manufacturer of both products, Nongshim, in South Korea and abroad, as well as its stock value, with an increase of 10 percentage points in the four days following the Oscars. As of June 2020, on Amazon US, the two types of South Korean instant noodles are being marketed and sold as a bundle under the title "Parasite noodle Ram Dom Jjappaguri = Neoguri+Jjapagetti" with more than 20 listings put up by Amazon and third-party sellers.

In Parasite, instant noodles is a metaphor for the social divide between the Kims and the Parks. The wealthy Parks enjoy the cheap snack topped with slices of expensive Korean beef-unlike the down-on-their-luck Kims who subsist on ungarnished instant noodles. "Every time the movie launches in each nation, jjappaguri goes viral on social media," said a spokesperson for Nongshim, which has been giving out free samples of the snack at theaters around the world in an effort to promote its brand along with the film (Kim 2020b). Nongshim has also put up YouTube videos of jjappaguri's recipe in 11 languages: English, Chinese, Japanese, Taiwanese, Thai, Indonesian, Vietnamese, German, Myanmarese, Spanish, and Portuguese (Official chapaguri recipe 2020). As of June 2020, a YouTube search turned up thousands of videos featuring jjappaguri specifically linked to Parasite.

Nongshim denied that jjappaguri's appearance in the film was intended as a product placement or advertisement. "Similar to how K-drama has driven the popularity of chimaek (fried chicken and beer), it is a great way to advertise Korea's food culture via such cultural contents," said a Nongshim spokesman (Jo 2020). The global audience may find Jjapaghetti and Neoguri to be novel but the two products have been steady-sellers for nearly three decades in South Korea's USD1.69 billion instant noodle domestic market. Nongshim rolled out Neoguri in 1982 and Jjapaghetti in 1984. In fact, jjappaguri is not even a new recipe; the combination of the two noodles first went viral in South Korea in 2009, when an online community user introduced it, and it later featured on various South Korean reality TV shows (Jo 2020).

Parasite's filming locations in Seoul have become hotspots for locals and foreign tourists alike. Since Parasite's Academy Awards triumph, places shown in the film that have resonated with Parasite audiences-including the Pig Rice supermarket where Ki-woo drinks soju spirit with a friend, the stairway leading to the Jahamun tunnel through which the Kims made their escape, and the Sky Pizza shop that employs the family to fold boxes for a pittance-have been bustling with visitors and tourists (Kim 2020b). They have already been prominently featured on Seoul City's tourism website www.visitseoul.net, with the city government offering guided city tours to the film sites as part of its tourism programming (Parasite tour course takes you, n.d.).

The local government in Goyang City has made plans to restore the Goyang Aqua Special Shooting Studio set, where Parasite was produced, and to market it as a Parasite movie experience tourism facility (Kim 2020c). In addition, the local government will invest USD150 million in the development of the Goyang Film Culture Complex by 2026 to accommodate film-experience tourism facilities, additional indoor studios, outdoor set production facilities, inter-Korean video content centers, and image research and development companies (Kim 2020c).

\section{Nationalizing a global success}

The South Korean players-just like the instant noodles companies and local government officials capitalizing on Parasite's cultural dissemination of South Korean flavors and landmarks-were quick to embrace the film's success as a source of national pride. Bong's very first Oscar for Parasite was for Best Original Screenplay. Taking the stage with co-writer Han Jin-won, Bong thanked the Academy for the "great honor," and said in Korean that "writing a script is a very lonely process, you never write to represent your country." He added emphatically, this time speaking in English: "But this is the very first Oscar for South Korea!" Parasite's executive producer and financial backer Miky Lee, in a postOscars interview with CNN, described herself as a cultural envoy for South Korea and said she was driven by a belief that the world would love her country's cultural content-for its unique and edgy quality not found elsewhere-if it were exposed to it more (Miky Lee on Parasite 2020).

Parasite's Oscar wins ignited online celebrations in South Korea, as the country erupted in collective national pride over the success of its home-grown film. Messages of congratulations and joy appeared on social media platforms, with \#Parasite and \#DirectorBongJoonho trending atop Twitter in South Korea, while leading local web portal Naver was dominated by Parasite-related searches 
(Park and Brzeski 2020). After the film's Oscar wins, Parasite fever hit South Korea with movements to erect a Boon Joon-ho statue and museum in his hometown of Daegu, and to rename local streets in his honor.

South Korean president Moon Jae-in also tweeted his pride at Parasite's success (Kim and Lee 2020, 2020). Parasite "has moved the hearts of people around the world with a most uniquely Korean story," tweeted Moon in English in a striking departure from his usual Korean tweets. Alluding to COVID-19 as "difficulties" faced by South Koreans, he wrote:

I join all Koreans in congratulating the film "Parasite" for winning Oscars in four categories at the Academy Awards, including Best Director and Best Picture. I am proud of director Bong Joon Ho, the actors and crew. I am especially grateful to them for instilling pride and courage in our people as we come together to weather difficulties.

Parasite has moved the hearts of people around the world with a most uniquely Korean story. The film has proven its potential to the world through its distinctive and detailed direction, lines that resonate, original screenplay, film editing, musical score and production design, on top of the actors' performances. Taking home four Oscars, after winning the Palme d'Or at the Cannes Film Festival last year, can be attributed to the accumulated efforts of every Korean filmmaker over the past 100 years. I am very pleased to see a Korean film stand shoulder to shoulder with those of other countries and mark the beginning of another 100 years of Korean filmmaking...The Government will stand with those in the film industry so that they can stretch their imagination to the fullest and make movies free from worries. I am already curious about what director Bong Joon Ho, the actors and crew will be working on next. Congratulations once again on winning the awards, and I, together with the people, will always cheer you on.

Moon said his government would continue to support Korean cinema as he started his cabinet meeting with a round of applause for Parasite. South Korean Culture Minister Park Yang-woo was also quoted by Yonhap: "I am sure the wins will widely open up a new 100-year period for our cinematic history as well as the globalization of hallyu" (Cameron 2020).

In essence, Parasite is not just any film; it is a quintessential South Korean film branded as such and engineered by South Korean resources and talents to compete for global consumption and recognition.

\section{A nation brand: concepts and sentiments}

To explicate South Korea's nation brand vis-à-vis Parasite as outcomes, a Leximancer analysis was conducted to investigate the concepts that are associated with Parasite as "a complex bundle of images, meanings, associations and experiences in the minds of people" (Fan 2010, p. 98) internationally. Based on a period of analysis of May 1, 2019 through June 17, 2020, a keyword search for the film Parasite produced 8808 English-language texts comprising 8180 newspaper articles, 215 magazine articles, 256 broadcast news transcripts, and 157 trade publication articles.

Leximancer is a text mining software that scientometrically describes and analyzes content of collections of textual documents. In Leximancer, a word is defined by its context in usage, and the co-occurrence of words is an important means for enabling the narrative inquiry on a subject (Smith and Humphreys 2006; Lee and Jeong 2008). Based on this contextual approach, co-occurring words reflect meaning. Leximancer identifies concepts within the text as focused clusters of related, defining terms as conceptualized by the author and not according to a predefined dictionary or thesaurus in other words, a concept is a group of related words that travel together in the text. Evidence words include synonyms and adjectives. Leximancer concepts begin with seed words, which are the keywords that are weighted according to how frequently they occur in sentences containing the concept, compared to how frequently they occur elsewhere. The Leximancer learning process then evolves the seed-word definitions into a full thesaurus to generate concepts that are word-like or name-like (proper names such as Michael or United States). Through this process, Leximancer uses empirically validated algorithms to determine the most frequently used concepts within a body of text and the relationships between the concepts to provide associational analysis of textual data.

A Leximancer analysis found 11 concepts ranked by their frequency of occurrence in the text to reveal their significance as the central organizing ideas in the texts about Parasite. In descending order of importance, the 11 concepts are South Korea, Korean Wave, Oscars/Academy Awards, Bong Joon-ho, culture, pride, disparity, national, investment, social, and wealth. The ranked concept list suggests that the texts overwhelmingly associate Parasite with the country of South Korea and its most significant cultural export, the Korean Wave, thus helping to reinforce the nation branding of the film as a tangible South Korean national resource. 


\section{Sentiments toward South Korea}

A Social Studio analysis of 19,743 Twitter and Instagram posts between May 1, 2019 and June 17, 2020 about Parasite also shows mostly favorable sentiments, with $82.3 \%$ positive posts.

To further assess how the film Parasite is viewed by others, a sentiment analysis was conducted through Leximancer, this time to extract subjectivity in the texts to measure "the attitude of a speaker or writer towards a concept, whether they express something positively or negatively" (Ward et al. 2014). Sentiment refers to subjective feelings, rather than facts, and includes people's attitudes, emotions, and opinions (Mullen 2017). Sentiment analysis has been used in many studies including customer reviews of hospitality organizations such as hotels, restaurants, and cruises (Ma et al. 2018), public perceptions of Australia's homestay initiative for asylum seekers (Hebbani and Angus 2016), and international sentiments toward Singapore as host of the 2018 Trump-Kim Summit (Kim and Lee 2018).

A sentiment analysis of the 8808 texts using Leximancer reveals an overwhelming representation of positive sentiments toward Parasite, with $88 \%$ of texts showing positive mentions. The overall likelihood scores of the Leximancer concepts indicate that they are mostly positive. "South Korea" is the positive concept with the highest likelihood score at $90 \%$. Likelihood scores describe the conditional probability of the text segments within a concept also containing another concept (Leximancer 2011). This means that $90 \%$ of the text segments with the term "South Korea" contain positive sentiments. The other positive concepts with high likelihood scores are "Korean Wave" (89\%); Bong Joon-ho (88\%) "Oscar/Academy Awards" (86\%); culture $(84 \%)$, pride (84\%), national (80\%), and investment (71\%) (see Table 1).

The remaining three concepts are more mixed or negative in sentiment; "Disparity" is the negative concept with the highest likelihood score at $58 \%$, meaning that $58 \%$ of

Table 1 Likelihood Scores of Each Leximancer Concept $(n=8808)$

\begin{tabular}{llll}
\hline Concept & $\begin{array}{l}\text { Positive like- } \\
\text { lihood (\%) }\end{array}$ & Concept & $\begin{array}{l}\text { Negative } \\
\text { likelihood } \\
(\%)\end{array}$ \\
\hline South Korea & 90 & Disparity & 58 \\
Korean Wave & 89 & Wealth & 35 \\
Bong Joon-ho & 88 & Social & 33 \\
Oscar/Academy Awards & 86 & & \\
Culture & 84 & & \\
Pride & 84 & & \\
National & 80 & & \\
Investment & 71 & & \\
\hline
\end{tabular}

the text segments with the term "disparity" contain negative sentiments, followed by the concepts of "wealth" and "social," with 35\% and 33\% likelihood scores.

In conclusion, the sentiment analysis reveals that positive sentiments are more likely to be associated with the nation brand of South Korea and the Korean Wave rather than the negative elements highlighted in the film such as economic and social disparities that were highlighted in the film.

\section{Conclusion}

This study addresses a gap in the literature by addressing a single cultural product - in this case, the film Parasite, to better understand the dynamics of South Korea's cultural diplomacy and nation branding. The findings suggest that Parasite fits into a framework of cultural diplomacy "explicitly implemented in a top-down and unilateral approach by government to enhance national prestige abroad, underpinned by the institutional legacy of a 'developmental state' model of governance that is implicitly associated with capacity building of the domestic cultural industries through promoting international cultural exchange" (Kang 2015, p. 433). As seen in the case of Parasite, the government, despite claiming the film as its national resource consistent with a soft power approach, has undertaken a balancing act to navigate competing priorities and tensions.

The South Korean government has strategically appropriated cultural products domestically to boost its nation brand as well as to legitimize governmental efforts in developing domestic cultural industries, given their importance to the country's economy. Yet in response to some of the negative ramifications of the dominance of the Korean Wave in some countries, less emphasis has been placed on an explicit cultural export agenda, leading to an increasingly depoliticized and decentralized approach to facilitating international cultural exchange (Kang 2015). The government policy will likely remain top-down and unilateral while drawing on expanding private-sector resources, as seen in the case of Parasite, especially after the film's success as a cultural diplomacy and nation branding tool.

Consistent with the growing depoliticalization and decentralization of its cultural diplomacy approach, the government has adopted a more measured approach in using and managing cultural assets for political and economic purposes on the global stage. Considering also neoliberalist pressures, this cautious stance is a direct response to "anti-Korean Wave" movements and slogans in Japan, China, Taiwan, Thailand, and Vietnam that suggested that the ascent of the Korean wave has prompted an uneasiness about non-reciprocal cross-cultural exchanges (Jang and Paik 2012; Kim 2018; Kim and Lee 2014; Lee 2009). Some of the concerns raised viewed the Korean Wave-with its influences on young 
people's hairstyles and fashion-as a form of cultural invasion into their national cultures (Kim 2018).

In one of the earliest backlashes against the Korean Wave, in 2005, China's State Administration for Radio Film and Television declared that China had been too generous with the import of Korean TV dramas and called for a stricter screening process. It also said China should limit airtime for Korean dramas to 50\%. Soon after, China Central Television said it would reduce the amount of time allotted to soap operas from Korea. Beijing TV next announced it would be showing more Hong Kong and Taiwan-made soap operas instead (Cai 2011). Anti-Korean Wave sentiments also weakened diplomatic ties with China and Japan over alleged inaccuracies in South Korean cultural contents' portrayals of ancient Korea-China relations and depictions of Japan and Japanese people (Park 2014; Kim 2018). In 2016, South Korean cultural exports suffered from a prolonged downturn in the Chinese market, which had been the biggest buyer of K-dramas, due to the Beijing's prohibition of South Korean content in retaliation of Seoul's decision to deploy a Terminal High Altitude Area Defense system.

Lee (2009) suggested that while the Korean Wave can still be creatively mobilized to achieve foreign policy goals, "too deliberate an attempt to use cultural assets for economic and political purposes will provoke backlashes as in the case of anti-Korean Wave movements and slogans" from other countries (p. 135). Lee (2011) noted that "the Korean Government should not take a forefront role in the promotion of its Korean Wave" because "if the state support or lead, it can cause serious problems. Like a free market economy, let the culture spread itself naturally. The state has not to take the main character in the stage of entertainment business" (cited in Jang and Paik 2012, p. 201).

In Parasite's case, there is no clear evidence of the government's attempt to control the message, consistent with a depoliticized and decentralized approach. The film's message on inequality "is a sharp critique of South Korea's modern society" as director Bong directs his audience to many scenes around Seoul to highlight the divide between the haves and have-nots, and the parasitic relationships between them (Shin 2020). South Korea's income distribution is highly skewed; in 2015 , the top $10 \%$ of South Koreans held $66 \%$ of the nation's wealth, while the poorer half held only $2 \%$ (Chen 2019). While inequality in South Korea is not necessarily worse than many other countries, the concept has exploded onto the South Korean political scene and cultural contents in recent years amid runaway home prices, high youth unemployment, and a stagnating economy, undermining support for Moon and his ruling Democratic Party of Korea. Moon, who came into power in 2017 pledging to narrow the income gap and create more opportunities for the poor, have raised taxes and increased the minimum wage but has been unable to stem the widening income gap.
Although Parasite paints a negative picture of South Korea's economic and social disparities, sentiments toward South Korea, vis-à-vis Parasite, appeared to be still largely positive, as seen in the Leximancer analysis. As a black comedy, what Parasite conveys about social injustice and the disparities in South Korea may be less real or urgent to audiences outside South Korea. The issues raised in Parasite may resonate more with South Koreans because it contains many references to current events there that had infuriated South Koreans such as the scandals surrounding fake college credentials and Moon's predecessor and impeached president Park Geun-hye, who was famously captured on TV news hiding her hands behind her back to avoid physical contact with a supporter who tried to shake her hand-similar to the wealthy father in Parasite who recoils from the stench of a destitute man who is his loyal supporter.

In response to Parasite, the government has launched initiatives to improve the living conditions in semi-basement apartments. The government is partnering with the Korea Energy Foundation and the Seoul Metropolitan Government to offer up to 3.2 million won (USD2639) per household to enhance heating systems, replace floors, and install air conditioners, dehumidifiers, ventilators, windows, and fire alarms (Sharf 2020), but whether they will have any real impact in lifting South Korean families out of the poverty cycle remains highly doubtful.

\section{Compliance with ethical standards}

Conflict of interest The author states that there is no conflict of interest.

\section{References}

Ang, I., Y.R. Isar, and P. Mar. 2015. Cultural diplomacy: Beyond the national interest? International Journal of Cultural Policy 21 (4): $365-381$.

Anholt, S. 2007. Competitive identity: The new brand management for nations, cities, regions. Basingstoke, UK: Palgrave Macmillan.

Avraham, E. 2018. Nation branding and marketing strategies for combatting tourism crises and stereotypes toward destinations. Journal of Business Research 116: 711-720.

Bicker, L. 2020, February 11. What the Oscar win means for Korean cinema. BBC. https://www.bbc.com/news/world-asia-51449513

Cameron, R. 2020, February 13. South Korean Brands celebrate 'Parasite' Oscar win in their marketing. Branding in Asia. https://www. brandinginasia.com/south-korean-brands-celebrate-parasite-oscar -win-in-their-marketing/

Cai, J. 2011. The first taste of Korean wave in China. journeyeast. tripod.com

Chen, B. X. 2019, Oct 30. 'Parasite' and South Korea's income gap: Call it dirt spoon cinema. New York Times.

Contents Industry White Paper. 2018. Korea creative content agency. http://www.kocca.kr/cop/bbs/view/B0000146/1840796 
Cull, N. 2008. Public diplomacy: Taxonomies and histories. The Annals of the American Academy of Political and Social Sciences 616 (1): $31-54$.

Cummings, M. 2003. Cultural diplomacy and the United States government: A survey. Washington, DC: Center for Arts and Culture.

Dinnie, K. 2008. Nation branding: Concepts, issues, practice. Oxford, UK: Butterworth-Heinemann.

Economic effects of Oscar-winning film 'Parasite.' 2020, February 17. Korean broadcasting system. https://www.world.kbs.co.kr/servi ce/contents_view.htm?lang $=$ e\&menu_cate $=$ business\&board _seq $=379867$

Elfving-Hwang, J. 2013. South Korean cultural diplomacy and brokering 'K-Culture' outside Asia. Korean Histories 4 (1): 14-26.

Fan, Y. 2006. Banding the nation: What is being branded? Journal of Vacation Marketing 12 (1): 5-14.

Fan, Y. 2010. Branding the nation: Towards a better understanding. Place Branding and Public Diplomacy 6 (2): 97-103.

Gudjonsson, H. 2005. Nation branding. Place Branding 1 (3): 283-298.

Harrison, H., Birks, M., Franklin, R., \& Mills, J. 2017, January. Case study research: Foundations and methodological orientations. Qualitative Social Research. https://doi.org/10.17169/ fqs-18.1.2655

Hebbani, A., and D. Angus. 2016. Charity begins at home: Public perceptions of the homestay initiative for asylum seekers in Australia. Australian Journalism Review 38 (1): 83-100.

Hollingsworth, J. 2020, February 14. Miky Lee: The godmother of South Korean cinema. CNN. https://www.cnn.com/2020/02/14/ asia/miky-lee-parasite-film-intl-hnk/index.html

Jang, G., and W.K. Paik. 2012. Korean Wave as tool for Korea's new cultural diplomacy. Advances in Applied Sociology 2 (3): 196-202.

Jin, D.Y. 2016. New Korean Wave: Transnational popular culture in the age of social media. Urbana: University of Illinois Press.

Heo, I.H. 2015. Neoliberal developmentalism in South Korea: Evidence from the green growth policymaking process. Asia Pacific Viewpoint 56 (3): 351-364.

Jin, D. Y. 2020, May 26. The Korean Wave. George Journal of International Affairs. https://www.gjia.georgetown.edu/2020/05/26/ the-korean-wave/

Jo, H. 2020, Feb 11. Nongshim ups promotion of 'ram-don' from 'Parasite.' Korea Herald. http://www.koreaherald.com/view. php?ud=20200211000702

Kang, H. 2012, Aug 26. Jun Kwang-ryul to visit Iraq. Yahoo News. https://www.news.yahoo.com/jun-kwang-ryul-to-visit-iraq-14595 2442.html

Kang, H. 2015. Contemporary cultural diplomacy in South Korea: Explicit and implicit approaches. International Journal of Cultural Policy 21 (4): 433-447.

Kim, H.S. 2017. The Korean Wave as soft power public diplomacy. In The Routledge handbook of soft power, ed. N. Chitty, J. Li, G. Rawnsley, and C. Hayden, 414-424. New York: Routledge.

Kim, H.S. 2018. When public diplomacy faces trade barriers and diplomatic frictions: The case of the Korean Wave. Place Branding and Public Diplomacy 14 (4): 234-244.

Kim, J. 2020a. K-pop, hallyu continue global rise. Korea Times. https ://www.koreatimes.co.kr/www/nation/2020/01/356_281957.html

Kim, Y. W. 2020b, February 24. The 'Parasite' impact. Korea Herald. https://www.thejakartapost.com/life/2020/02/23/the-paras ite-impact.html

Kim, S. J. 2020c, February 28. Seoul to promote 4 'Parasite' shooting locations as tour attractions. Korea Times. https://www.koreatimes .co.kr/www/nation/2020/02/281 283407.html

Kim, H. S., \& Lee, S. T. 2020. Peace talks: Public diplomacy and place branding in the 2018 Trump-Kim summit in Singapore. Place Branding and Public Diplomacy.
Kim, S., \& Lee, J. 2020, Feb 13. Shock 'Parasite' Oscar showcases Korea's growing soft power. Bloomberg. Retrieved from https:// www.bloomberg.com/news/articles/2020-02-10/shock-oscar-forparasite-showcases-korea-s-growing-soft-power

Kim, J.Y., and J.O. Lee. 2014. Korean pop culture: A decade of ups and downs. International Journal of Multimedia and Ubiquitous Engineering 9 (3): 129-134.

Kim, T.Y., and D.Y. Jin. 2016. Cultural policy in the Korean Wave: An analysis of cultural diplomacy embedded in presidential speeches. International Journal of Communication (online) 10: 21.

Korean Development Institute. n.d. https://www.eiec.kdi.re.kr/policy/ domesticView.do?ac $=0000148436$

Lee, G. 2009. A soft power approach to the 'Korean Wave'. The Review of Korean Studies 12 (2): 123-137.

Lee, J. 2011. Personal interview. Seoul. 18 September.

Lee, H.K. 2013. Cultural policy and the Korean Wave: From national culture to transnational consumerism. In The Korean Wave, ed. Y. Kim, 201-214. New York: Routledge.

Lee, B., and Y.-I. Jeong. 2008. Mapping Korea's national R\&D domain of robot technology by using co-word analysis. Scientometrics 77 (1): 3-19.

Leximancer. 2011. Leximancer manual version 4. www.leximancer .com/site-media/lm/science/Leximancer_Manual_Version_4_0. $\mathrm{pdf}$

Lovric, B. 2018. From film stories to national soft power: Policies and film content of South Korea, Japan, and China. In The Palgrave handbook of Asian cinema, ed. A.H.J. Magnan-Park, G. Marchetti, and S.K. Tam, 609-630. London: Palgrave Macmillan.

Ma, E., M. Cheng, and A. Hsiao. 2018. Sentiment analysis: A review and agenda for future research in hospitality contexts. International Journal of Contemporary Hospitality Management 30 (11): 3287-3308.

Mark, S. 2009. A greater role for cultural diplomacy (pp. 1-51). Institute of International Relations. Netherlands: Clingendael.

Miky Lee on 'Parasite' and the global rise of Korean culture. 2020, February 18. CNN. https://www.cnn.com/videos/world /2020/02/18/miky-lee-parasite-rise-of-south-korea-sot-ywt.cnn

Ministry of Culture, Sports, and Tourism, ROK Ministry of Culture, Sports and Tourism website: History of Ministry of Culture, Sports and Tourism, 2018. http://www.mcst.go.kr/english/about us/history.jsp.

Ministry of Foreign Affairs and Trade. 2010. Cultural diplomacy manual. Seoul (in Korean).

Mullen, T. 2017. Introduction to sentiment analysis. https://www.lctmaster.org/files/MullenSentimentCourseSlides.pdf

Nye, J. 2004. Soft power and American foreign policy. Political Science Quarterly 119 (2): 255-270.

Nye, J. 2008. Public diplomacy and soft power. Annals of the American Academy of Political and Social Science 616 (1): 94-109.

Nye, J. 2009, Nov 10. South Korea's growing soft power. https://www. project-syndicate.org/commentary/south-korea-s-growing-softpower?barrier=accesspaylog

Nye, J., and Y. Kim. 2013. Soft power and the Korean Wave. In The Korean Wave: Korean media go global, ed. Y. Kim, 31-42. Abingdon: Routledge.

Parasite tour course that takes you to the shooting locations. n.d. Visitseoul.net. http://www.english.visitseoul.net/hallyu/Parasite-tourcourse_/32561

Official chapaguri recipe (feat. Chapagetti, Neoguri) (a.k.a. Ram-don, jjapaguri). 2020, February 10. Youtube. https://www.youtube.com/ watch? $=$ DEWi7n8jo04

Park, S. S. 2014. Anti-hallyu voice growing in Japan. Korea Times. http://www.koreatimes.co.kr

Park, S., \& Brzeski, P. 2020, February 10. South Korea erupts in celebration as 'Parasite' makes Oscar history. Hollywood Reporter. 
https://www.hollywoodreporter.com/news/south-korea-reacts-asparasite-makes-oscars-history- 1278340

Sharf, Z. 2020, February 24. After historic 'Parasite' run, South Korea vows to improve semi-basement apartments. IndieWire. https:// www.indiewire.com/2020/02/parasite-south-korea-improve-semibasement-apartments-1202213182/

Shin, H. 2020. 'Parasite' reflects deepening social divide in South Korea. Reuters. https://www.reuters.com/article/us-awards-oscar s-southkorea-inequality/parasite-reflects-deepening-social-divid e-in-south-korea-idUSKBN20414L

Szondi, G. 2008. Public diplomacy and nation branding: Conceptual similarities and differences. Clingendael: Netherlands Institute of International Relations.

Quelch, J., and K. Jocz. 2004. Positioning the nation-state. Place Branding 1 (1): 74-79.

Scott, N., A.S. Ashton, P. Ding, and H. Xu. 2011. Tourism branding and nation building in China. International Journal of Culture, Tourism and Hospitality Research 5 (3): 227-234.

Smith, A.E., and M.S. Humphreys. 2006. Evaluation of unsupervised semantic mapping of natural language with Leximancer concept mapping. Behavior Research Methods 38 (2): 262-279.

Soft Power 30 Index. 2019. South Korea. https://www.softpower3 0. com/country/south-korea/

Son, I. 2020, March 10. 'Parasite' and viewing a film in one's imagination to overcome cultural barriers. FFWPU International. http:// www.familyfedihq.org/2020/03/parasite-and-viewing-a-film-inones-imagination-to-overcome-cultural-barriers/

Vandenburg, L. 2019, November 8. 'Parasite': Moving beyond "foreign.” The Diplomat. https://www.thediplomat.com/2019/11/paras ite-moving-beyond-foreign/

Volcic, Z., and M. Andrejevic. 2011. Nation branding in the era of commercial nationalism. International Journal of Communication 5: 598-618.

Ward, V., West, R., Smith, S., McDermott, S., Keen, J., Pawson, R., $\&$ House, A. 2014. The role of informal networks in creating knowledge among health-care managers: a prospective case study. Health Services and Delivery Research, 2(12).

Xu, A., \& Hahm, H. 2018, May 17. Hallyu exports hit USD8.2 billion. Korea Net. http://www.korea.net/NewsFocus/Culture/view?artic leId $=159075$

Yin, R. 1984. Case study research: Design and methods, 1st ed. Newbury Park: Sage.

Yin, R. 2002. Case study research: Design and methods, 3rd ed. Thousand Oaks: Sage.

Yin, R. 2014. Case study research: Design and methods, 5th ed. Thousand Oaks: Sage.

Yoo, J. (2018). The role of official news releases of the Korean Ministry of Culture, Sports, and Tourism in the success of the Korean Wave. International Journal of Korean Studies, 22(2). http://www. icks.org/n/data/ijks/2018FW-1.pdf

Publisher's Note Springer Nature remains neutral with regard to jurisdictional claims in published maps and institutional affiliations.

Seow Ting Lee is professor of strategic communication and health communication in the Department of Advertising, Public Relations and Media Design at the University of Colorado in Boulder. Her research examines organization-stakeholder communication strategies and practices, with an emphasis on new media. Her research has been published extensively in leading, peer-reviewed journals including Journal of Communication, Public Relations Review, Journal of Public Relations Research, Journal of Health Communication, Health Communication, Media Culture and Society, Mass Communication and Society, HealthPromotion International, Journal of Mass Media Ethics, and Place Branding and Public Diplomacy. 